\title{
Clinical and Radiological Characteristics of Patients with Symptomatic Internal Carotid Artery Stenosis and Early and Late Outcomes of Carotid Artery Stenting
}

\author{
Semptomatik Internal Karotis Arter Stenozu Olan \\ Hastaların Klinik ve Radyolojik Özellikleri ve Karotis Arter \\ Stentlemesinin Erken ve Geç Dönem Sonuçları
}

Hasan Huseyin Kozak ${ }^{1}$,

Osman $\mathrm{Koc}^{2}$,

Ali Ulvi Uca ${ }^{1}$,

Osman Serhat Tokgoz ${ }^{1}$,

Figen Guney ${ }^{1}$,

Mustafa Altas ${ }^{1}$

${ }^{1}$ Necmettin Erbakan University, Meram Faculty of Medicine, Department of Neurology, Konya, Turkey

${ }^{2}$ Necmettin Erbakan University, Meram Faculty of Medicine, Department of Interventional Neuroradiology, Konya, Turkey

Geliş Tarihi/Received: 27 May 2020

Kabul Tarihi/Accepted: 17 August 2020

Address correspondence to: Hasan Hüseyin Kozak, Necmettin Erbakan University, Meram Faculty of Medicine, Department of Neurology, Konya, Turkey

e-mail: hhkozak@gmail.com

\section{ORCID}

Hasan Hüseyin Kozak

https://orcid.org/0000-0001-6904-8545

Osman Koc

https://orcid.org//0000-0003-2123-4589 Ali Ulvi Uca

https://orcid.org/0000-0002-5783-8061

Osman Serhat Tokgoz

https://orcid.org/0000-0002-4919-0285

Figen Guney

https://orcid.org/0000-0002-8572-8919

Mustafa Altas

https://orcid.org/0000-0003-3011-1062
Öz

Amaç: Karotis arter stentleme (KAS) serebrovasküler hastalıklarda karotis endarterektomiye alternatif olarak kullanılan bir yöntemdir. Serebral koruma cihazlarının geliştirilmesi ile bu işlemin uygulanabilirliği artmıştır. Bu çalışmada, KAS uygulanan hastaların klinik ve radyolojik özellikleri ile erken ve geç dönem sonuçları araştırıldı.

Hastalar ve Yöntem: 2008 ile 2014 yılları arasında üniversite hastanesine başvuran ve internal karotis arter (IKA) darlığı saptanıp KAS uygulanan 76 hastanın (54 erkek, 22 kadın) klinik ve radyolojik özellikleri, stentleme sonrası erken ve geç dönem sonuçları geriye dönük olarak incelendi.

Bulgular: Başvuruları sırasında tüm hastalar semptomatikti ve yapılan tetkikler sonrasında IKA darlı̆̆ı tespit edildi. 62 hastada tek taraflı (sağ IKA, \%34,2 sol IKA \%47,4) 14 hastada bilateral $(\% 18,4)$ darlık saptandı. Ortalama darlık derecesi 82,1 (Standart sapma: 11,36, Aralık:60-99\%) idi. Tüm hastalar IKA darlığı için stentleme ile tedavi edildi (teknik başarı oranı: \%100). Iş̧lemler esnasında herhangi bir komplikasyon gelişmedi. 1 yıllık takip süresince hiçbir hastada tekrarlayan iskemik atak olmadı. Karotis arter hastalığı; hipertansiyon, hiperlipidemi, diyabetes mellitus, koroner arter hastalığı, geçirilmiş serebrovasküler olay ve geçici iskemik atak öyküsü ile yüksek oranlarda ilişkiliydi.

Sonuçlar: Karotis arter hastalıkları, eşlik eden hastalıklar ve geçirilmiş serebral vasküler olaylar ile birlikte son derece önem arz etmektedir. KAS uygulaması, iyi seçilmiş ve risk analizlerinin medikal tedaviler ile birlikte yapıldığı olgularda ciddi komplikasyon oranının düşük olması nedeniyle güvenle kullanılabilecek bir yöntemdir.

Anahtar Kelimeler: Ateroskleroz, karotis arter, endovasküler tedavi, klinik sonuçlar

\section{Abstract}

Aim: Carotid artery stenting (CAS) is an alternative approach to carotid endarterectomy in cerebrovascular diseases. The applicability of this procedure has increased as a result of development of cerebral protection devices. In the trial, the clinical and radiological characteristics and early and late outcomes of patients who received CAS were investigated.

Patients and Methods: The study had a retrospective design. The clinical and radiological characteristics and early and late outcomes after CAS of 76 patients ( 54 male, 22 female) who were admitted to a university hospital between 2008 and 2014 due to a diagnosis of internal carotid artery stenosis (ICA) were retrospectively reviewed.

Results: All patients were symptomatic during their admissions, and after their workups were completed, ICA stenosis was determined. Unilateral (Right ICA $34.2 \%$, left ICA $47.4 \%$ ) stenosis in 62 patients and bilateral stenosis $(18.4 \%)$ in 14 patients were determined. The mean degree of stenosis was 82.1 (SD:11.36, range: $60-99 \%$ ). All patients were treated with stenting for ICA stenosis (technical success rate: $100 \%$ ). No complications occurred during these procedures. During the one-year follow-up, no recurrent ischemic attack occurred in any patients. Carotid artery disease is highly associated with hypertension, hyperlipidemia, diabetes mellitus, coronary artery disease, a history of cerebrovascular accidents and transient ischemic attack.

Conclusions: Carotid artery disease is a critical factor with co-morbidities and history of cerebrovascular incidents. The carotid artery stenting (CAS) procedure is a method that can be used safely because its serious complication rate is low in cases that are well-selected and have had risk analyses performed regarding medical treatments.

Key words: Atherosclerosis, carotid artery, endovascular treatment, clinical outcomes
Cite this article as: Kozak HH, Koc O, Uca AU, Tokgoz OS, Guney F, Altas M. Clinical and Radiological Characteristics of Patients with Symptomatic Internal Carotid Artery Stenosis and Early and Late Outcomes of Carotid Artery Stenting. Selcuk Med J 2020;36(4): 288-295
Disclosure: None of the authors has a financial interest in any of the products, devices, or drugs mentioned in this article. The research was not sponsored by an outside organization. All authors have agreed to allow full access to the primary data and to allow the journal to review the data if requested. 


\section{INTRODUCTION}

Morbidity and mortality due to stroke constitute a major health problem. The most common cause of all strokes is atherosclerotic disease of the carotid arteries. ICA stenosis is one of the major causes of ischemic stroke. While the frequency of ICA stenosis for people in their sixties is $0.5 \%$, it reaches $10 \%$ for people over the age of $80(1,2)$. It was reported in the literature that, in asymptomatic patients who have $50 \%$ carotid artery stenosis, the risk of ipsilateral stroke in a five-year period is $4 \%$, with it is $8 \%$ in patients with $70 \%$ stenosis (3). In the literature, the ipsilateral stroke or mortality rate of cases with asymptomatic carotid artery stenosis was found as $10.9 \%$ in their 5-year optimal medical treatment and follow-up (4). On the other hand, in cases with symptomatic carotid artery stenosis, the 2-year mortality or stroke rate was found very high as $26 \%(5,6)$. Especially case groups with multiple risk factors and advanced stenosis are considered to be a riskier group for secondary stroke. Being at or over the age of 65 , being male and having a history of coronary artery disease and hypertension are at the top of significant clinical risk factors (7).

The North American Symptomatic Carotid Endarterectomy Trial (NASCET), the European Carotid Surgery Trial and many clinical trials conducted in recent years have shown the benefits of carotid revascularization by using carotid artery stenting (CAS) or carotid endarterectomy (CEA) in patients with symptomatic carotid stenosis (8-13). It is thought that arterial revascularization by endarterectomy or stenting has positive contributions to the clinic of stroke at the early and late stages of stroke (14). Since significant studies published in 1990s, CEA has become prominent as a first-step treatment for symptomatic patients with carotid stenosis between $50 \%$ and $99 \%(15,16)$. Today, especially with newly developed devices and methods, CAS has started to become an acceptable treatment method alternative to standard CEA $(17,18)$. In the last decade, the use of CAS has increased, and it constitutes approximately $17 \%$ of all carotid revascularization procedures in the USA $(19,20)$.

So far, there has been 20 RCTs investigating the effectiveness and safety of stenting for endarterectomy and carotid stenosis $(21,22)$. Despite different study designs, these RCTs and their meta-analyses provided similar results: CEA has a lower risk of periprocedural stroke; in CAS, there is a lower risk of periprocedural myocardial infarction (MI), cranial nerve damage and operation region hematoma. After excluding periprocedural strokes (strokes occurring within 30 days of the intervention), neither CAS nor CEA presented results that showed their superiority over the other in the long run in terms of reducing the risk of ipsilateral stroke in patients with symptomatic occlusive carotid diseases (23). Beyond the periprocedural period, carotid stenting is as effective in preventing recurrent stroke as endarterectomy (24).

In particular, CAS is indicated as an alternative to CEA in the presence of factors that increase the risk of open surgery, such as contralateral carotid occlusion, high carotid bifurcation, carotid dissection, contralateral vocal cord paralysis, prior neck irradiation, tracheostomy and those who cannot medically tolerate anesthesia. Moreover, CAS may be considered for those with standard surgical risk and symptomatic carotid stenosis if there are factors that decrease the risk of endovascular intervention such as age less than 70 years, last symptomatic episode more than 2 weeks prior, low burden of age-related white matter changes, experienced interventionalist team, a single short noncalcified plaque without intraluminal thrombus or favorable aortic arch anatomy without significant atheromatous burden (25).

With newly developed endovascular intervention methods, reductions in the rates of the aforementioned complications and long-term positive outcomes regarding patient comfort and new methods that emerged with these techniques have continuously broadened the indication area of CAS. The increasingly abundant data accumulation in this field will lead to a clearer assessment of outcomes. In the light of the information above, this study aimed to contribute to the literature on revascularization with clinical results that may expand the assessment area of the existing literature by investigating the clinical and radiological characteristics of patients receiving carotid artery stenting, applicability and safety of stenting in groups with multiple risk factors and its long-term clinical outcomes.

\section{PATIENTS AND METHODS} Data collection

The study had a retrospective design and included 76 patients who received the CAS procedure due to atherosclerotic ICA stenosis at Necmettin Erbakan University in the Meram Faculty of Medicine in Konya, Turkey between 2008 and 2014. Symptomatic patients, that is, patients who experienced a cerebrovascular accident (CVA), a transient ischemic attack (TIA) or 
an attack accompanied by focal neurological signs, in whom carotid artery stenosis was evaluated according to the NASCET criteria (26) and with an ICA stenosis more than $50 \%$ were selected for the trial. The eligibility criteria for the patients included stenosis of $50 \%$ or more of the diameter of the artery in angiography, $70 \%$ or more in ultrasonography or $70 \%$ or more in computed tomographic angiography or magnetic resonance angiography if the stenosis in ultrasonography was 50 to $69 \%$. Data regarding age, sex, hypertension (HT), diabetes mellitus (DM), hyperlipidemia $(H L)$, coronary artery disease (CAD), congestive heart failure (CHF), atrial fibrillation (AF) (from patients' ECGs), coronary artery bypass graft operation (CABGO), chronic renal failure (CRF), use of antiaggregants and anticoagulants, history of CVA and/or TIA, history of CVA in family, clinical characteristics of carotid artery disease and clinical follow-ups after stenting including 30-day followups and first year follow-ups were collected from patient files and hospital records. The trial was performed in accordance with the Declaration of Helsinki and approved by the local ethics committee of the Necmettin Erbakan University, Meram Medical Faculty.

\section{Carotid angioplasty and stenting procedure, stent controls}

Endovascular treatment was carried out by an interventional neuroradiologist who had conducted at least 5000 extracranial-intracranial operations (carotid stenting, cerebral aneurysm-AVM, intracranial balloon angioplasty-stenting). For all patients, the procedure was performed under IV sedation. In two of the patients, brachial artery access was applied, and in 74 of the patients, femoral artery access was applied. After placing 5F short sheath, arcus aortography was obtained. As soon as placing the sheath, 100 iu/kg heparin bolus was given. The common carotid artery where the lesion was catheterized with a suitable catheter (5F VERTEBRAL or SIMMONS 2). Afterwards, angiographies were obtained in projections that showed the stenosis region best. Preoperative cerebral angiography images were also taken. An exchange length guidewire was placed with the tip in the distal common carotid artery (CCA) or in the external carotid artery, except for the stenotic area. After this, a long vascular sheath $(6 \mathrm{f}$ $90 \mathrm{~cm}$ ) was positioned at CCA. As the long vascular sheath, shuttle (COOK MEDICAL INC.) or destination (TERUMO) was used. In all stenting procedures, the embolic protection devices Spider (EV3) and
Emboshield (ABBOTT) were used. Self-opening tapered or non-tapered nitinol stents [Protoge (EV3) and Xact (ABBOTT)] were used. When needed, preand post-dilation balloon angioplasties (ABBOTT) were performed. To discard major embolism, postoperative cerebral angiography was ensured in all cases. The stenting procedure was performed with only one physician with the same angiography device (GE, Advantix). After the endovascular procedure, the patients were followed up for 48 hours with visits of 12-hour intervals by a clinician and with vital sign monitoring at the neurovascular unit.

\section{Statistical analysis}

Statistical analyses were performed with SPSS 16.0 for Windows (Statistical Package for the Social Sciences, Chicago, IL). Mean, median, frequency, percentages and standard deviation (SD) were used among the descriptive statistics of the data. The significance of the difference between the means of the groups was compared with One-Way ANOVA test. Chi-squared test was used in the analysis of the qualitative independent data. All significance levels were two-tailed and set on the level of 0.05 .

\section{RESULTS}

The mean age of the sample $(n=76)$ was $64.61 \pm 8.81$ (range: $46-80$ ) years. $22(28.9 \%)$ of the patients were female, and $54(71.1 \%)$ of them were male. $26(34.2 \%)$ of them had a right-sided ICA stenosis, $36(47.5 \%)$ of them had a left-sided ICA stenosis, and in $14(18.4 \%)$ of them had a bilateral ICA stenosis. The angiographic lesion degree was reported with a ratio of $60-69 \%$ in seven $(9.2 \%)$ of them, $70-79 \%$ in $21(27.6 \%), 80-89 \%$ in four $(5.3 \%)$ and $90-99 \%$ in $44(57.9 \%)$ (Table 1). There were no significant differences between the patient groups in terms of sociodemographic characteristics in the side and degree of carotid artery stenosis.

There was a history of hypertension in 54 (71.1\%) of the patients, hyperlipidemia in 35 (46.1\%), diabetes mellitus in 33 ( $43.4 \%$ ) and coronary artery disease in $24(31.6 \%)$. A left-sided ICA stenosis was reported as the most frequent type, occurring in $26(48.1 \%)$ of the hypertensive patient group, $17(48.6 \%)$ of the hyperlipidemic patient group, $19(57.6 \%)$ of the diabetic patient group and $13(54.2 \%)$ of the patient group of CAD (Table 1). It was determined that, before stenting, $62(81.6 \%)$ of the patients were on antiaggregant therapy, and eight $(10.5 \%)$ were on oral anticoagulant therapy. A left-sided ICA stenosis was diagnosed as the most frequent, occurring in 28 
Table 1. Clinical and radiological characteristics of the patients

\begin{tabular}{|c|c|c|c|c|c|}
\hline & & $\begin{array}{l}\text { Right ICA } \\
\text { Stenosis } \\
\mathrm{n}: 26\end{array}$ & $\begin{array}{l}\text { Left ICA } \\
\text { Stenosis } \\
n: 36\end{array}$ & $\begin{array}{l}\text { Bilateral ICA } \\
\text { Stenosis } \\
\mathrm{n}: 14\end{array}$ & $p$ \\
\hline \multicolumn{6}{|c|}{ Sociodemographic data } \\
\hline Age & $($ mean $\pm S D)$ & $66.58 \pm 8.24$ & $62.97 \pm 12.83$ & $61.57 \pm 10.81$ & 0.310 \\
\hline Sex, Male & n (\%) & $18(33.3)$ & $24(44.4)$ & $12(22.2)$ & $0.398^{a}$ \\
\hline Sex, Female & n $(\%)$ & $8(36.4)$ & $12(54.5)$ & $2(9.1)$ & \\
\hline \multicolumn{6}{|l|}{ Medical History } \\
\hline DM & n (\%) & $10(30.3)$ & $19(57.6)$ & $4(12,1)$ & $0.247^{b}$ \\
\hline $\mathrm{H}$ & n (\%) & $11(31.4)$ & $17(8.6)$ & $7(20)$ & 0.881 \\
\hline HT & $\mathrm{n}(\%)$ & $19(35.2)$ & $26(48.1)$ & $9(16.7)$ & 0.824 \\
\hline CAD & n (\%) & $6(25)$ & $13(54.2)$ & $5(20.8)$ & 0.516 \\
\hline $\mathrm{CHF}$ & n (\%) & $0(0)$ & $1(50)$ & $1(50)$ & 0.403 \\
\hline AF & n (\%) & $0(0)$ & $1(50)$ & $1(50)$ & 0.403 \\
\hline CABGO & n (\%) & $3(27.3)$ & $8(72.7)$ & $0(0)$ & 0.117 \\
\hline CRF & n (\%) & $2(40)$ & $2(40)$ & $1(20)$ & 0.941 \\
\hline Antiaggregant use & n (\%) & $20(32.3)$ & $28(45.2)$ & $14(22.6)$ & 0.144 \\
\hline Anticoagulant use & n (\%) & $1(12.5)$ & $5(62.5)$ & $2(25)$ & 0.392 \\
\hline History of CVA & $\mathrm{n}(\%)$ & $13(33.3)$ & $18(46.2)$ & $8(20.5)$ & 0.890 \\
\hline History of TíA & n (\%) & $13(39.4)$ & $16(48.5)$ & $4(12.1)$ & 0.421 \\
\hline Family history of CVA & n (\%) & $2(40)$ & $2(40)$ & $1(20)$ & 0.941 \\
\hline \multicolumn{6}{|c|}{ Stenosis degree } \\
\hline $60-69 \%$ & n (\%) & $4(15.4)$ & $2(5.6)$ & $1(7.1)$ & \\
\hline $70-79 \%$ & n (\%) & $6(23.1)$ & $10(27.8)$ & $5(35.7)$ & \\
\hline $80-89 \%$ & n (\%) & $0(0)$ & $3(8.3)$ & $1(7.1)$ & \\
\hline $90-99 \%$ & n (\%) & $16(61.5)$ & $21(58.3)$ & $7(50)$ & \\
\hline
\end{tabular}

ICA: Internal Carotid Artery DM: Diabetes Mellitus; HL: Hyperlipidemia; HT: Hypertension; CAD: Coronary Artery Disease; CHF: Chronic Heart Failure; AF: Atrial Fibrillation; CABGO: Coronary Artery Bypass Graft Operation; CRF: Chronic Renal Failure; CVA: Cerebrovascular Accident; TiA: Trans Ischemic Attack.

a: One-Way ANOVA test b: Chi-square test

(45.2\%) of the patients using antiaggregants and in five $(62.5 \%)$ using anticoagulants. $39(51.3 \%)$ of the patients experienced CVA, 33 (43.4\%) experienced TIA, and in five $(6.6 \%)$ of them, a family history of CVA was detected. Left-sided ICA stenosis was diagnosed in $18(46.2 \%)$ of the patients who experienced CVA and $16(48.5 \%)$ of the patients who experienced TIA (Table 1). There was no significant difference between the patient groups in terms of medical histories, previous illnesses, antiaggregant/anticoagulant drug use and the side effects of carotid artery stenosis.

An angiographic procedure success rate of $100 \%$ was determined for all patients. The patients with bilateral stenosis were treated with two procedures. There were no complications during the procedures. In three of the patients (3\%), minor strokes occurred following the procedure. These patients had completely returned to their normal clinical neurological statuses within a month. During the 30-day follow-ups of all patients, no complication or death due to the procedure occurred. During the one-year follow-up, there was no recurrent stroke or TIA. Within the first month of the radiological follow-up of one patient (n:1, 1.4\%), asymptomatic restenosis was detected. In-stent restenosis was not detected in serial Doppler ultra-sonographies performed in the first, third, sixth and twelfth months following the procedure, and the flow types and velocities were in normal ranges.

\section{DISCUSSION}

In this study, endovascular stenting method, one of the treatment options for carotid artery stenosis, was investigated. The mean age of the sample was $64.61 \pm 8.81$ years. There was a history of hypertension in $71.1 \%$ of the patients, hyperlipidemia in $46.1 \%$, diabetes mellitus in $43.4 \%$ and coronary artery disease in $31.6 \%$. Unilateral (Right ICA $34.2 \%$, left ICA $47.4 \%$ ) stenosis in 62 patients and bilateral (18.4\%) stenosis in 14 patients were determined. The mean degree of stenosis was $82.1 \%$. No complications occurred during these procedures. During the oneyear follow-up, no recurrent ischemic attack occurred in any patients.

Carotid artery stenosis is responsible for $30 \%$ of ischemic brain stroke cases (1). Atherosclerosis begins at an early age but only becomes symptomatic 
at an older age. With advancing age, not only the prevalence but also the severity of the disease begin to increase. In our study, the female to male ratio of the patient group was approximately one to three, and the mean age was 64 . It is stated in the literature that, in patients under the age of 70 , CAS and CEA have similar risks (5.8\% and $5.7 \%$ ), and for younger individuals, CAS intervention is as safe as CEA $(27,28)$. Furthermore, in the Carotid Revascularization Endarterectomy and Stenting Trial (CREST), while patients under the age of 70 benefited from CAS, for patients over the age of 70 , CEA was found to be beneficial.

Treatment of carotid artery stenosis mainly comprises three methods: medical, surgical and endovascular. Additionally, for patient groups with severe stenosis along with multiple risk factors and those who are at high risk for stroke, treatment of even $50 \%-60 \%$ stenosis is clinically significant. Being aged 65 or older, male and having hypertension and cardiac disease are clinically significant risk factors $(6,29,30)$. Medical treatment includes primary prophylaxis (rehabilitation and treatment of risk factors such as hypertension, diabetes, hyperlipidemia, smoking and sedentary lifestyle) and secondary prophylaxis (acetylsalicylic acid, dipyridamole, ticlopidine, clopidogrel or combinations). In our patient group, high rates of $\mathrm{HT}(71.1 \%), \mathrm{HL}(46.1 \%)$, DM (43.4\%) and CAD (31.6\%) were found in accordance with the literature (7). The risk of having a stroke depends on the severity of the stenosis, previous neurological symptomatology and the medical treatment applied so far. In our study, approximately $91 \%$ of the patients were under medical treatment (antiaggregant or anticoagulant) before endovascular treatment: $51.3 \%$ had experienced CVA, and $48.7 \%$ had experienced TIA.

It has been suggested that, in cases where carotid stenosis is over $50 \%$, medical treatment alone is not sufficient. If further examinations are delayed, and endovascular treatments are not evaluated, the patient is considered at a high risk for stroke and its associated risks (31). In the 1991 NASCET and ECTS trials, it was suggested that, while antiaggregant treatment had been applied prophylactically for many years, CEA decreases the risk of ischemic stroke in symptomatic cases in comparison to medical treatment. From this date forward, CEA has commonly been used $(26,32)$. CAS had arisen as an alternative treatment method because its ischemic stroke and death rate is high intra- and post-operatively with conditions such as advanced age, contralateral severe stenosis or occlusion, additional stenosis in ICA, CHF, restenosis due to CEA and stenosis secondary to radiotherapy $(27,33,34)$. CAS, which was originally used only for high-risk groups, has begun to be used in all patient groups along with the more common use of stents in general. Application of medical treatment methods before and after invasive treatment methods creates the basics of sufficient treatment and lessens the risk factors $(31,35)$. In asymptomatic patients with carotid stenosis of $>60 \%$, the incidence of stroke under medical treatment is reported as below $2.5 \%$ (36). The recurrence rate for stroke within the first two years in patients that experienced stroke due to symptomatic carotid artery stenosis under medical treatment is as high as $26 \%(6,15,27)$. Approximately $90.8 \%$ of our patient group was composed of high-rated (stenosis of $70 \%$ and above) patients, and approximately $58 \%$ of these patients had severe stenosis of $90 \%$ and above.

While the incidence of having stroke is $5.5 \%$ in symptomatic cases with stenosis of above $75 \%$, this rate in symptomatic cases with less severe stenosis is about $2 \%$. If TIAs accompany severe carotid stenosis, this rate, which is $10 \%$ for a one-year period, increases to $30 \%$ for a five-year period (37). In a CREST trial, in the stenting group, by the end of four years, this rate was calculated as $7.2 \%$ in terms of primary endpoints (stroke + death + 30-day Ml and concurrent stroke). For all cases, the four-year stroke/death rates were $6.4 \%$ for CAS: $8 \%$ for symptomatic patients and $4.5 \%$. for asymptomatic patients. Considering that the recurrence rate of stroke under medical treatment in the first two years reaches as high as $26 \%$ in patients who experienced stroke due to carotid artery stenosis $(6,38)$, the fact that none of the patients in our patient group experienced recurrent stroke and transient ischemic attack during the one year followup period reveals an important result which should be taken into account while considering appropriate medical treatments. CAS may bring substantially positive clinical results. In patient groups indicated by evaluation of the severity of stenosis, clinical history and ongoing medical treatment to whom CAS is applied, it is clear that the mortality and morbidity rates will decrease following CAS. Medical and economical burdens resulting from poor clinical outcomes are also issues that need to be highlighted.

In geriatric patients who have carotid artery stenosis, the frequency of co-morbidities increases the perception of complication risk for the decision- 
making physicians in evaluation of endovascular treatments. The groups considered to have high complication risk factors are over the age of 80 , and have malignant hypertension, severe congestive heart failure, pulmonary failure, renal failure or contralateral carotid occlusion. Developed endovascular technology and increased interventional operation experiences of clinicians lead to high rates of success for endovascular treatment (25). In our study, an angiographic procedure success rate of $100 \%$ was determined for all patients. The patients with bilateral stenosis were treated with two procedures. There were no complications during the procedures. In three of the patients $(3 \%)$, minor strokes occurred following the procedure. These patients had completely returned to their normal clinical neurological statuses within a month. Various technical developments have improved the safety profile of CAS. Usage of embolic protection devices that have been shown to reduce embolism risk during stenting is not a prevalent practice. Through the use of embolism-blocking filters, the frequency of embolus related to stenting has been decreased. Embolism-blocking filters make it possible to place a stent in a patient without stopping blood flow, and they even make the treatment of cases in which contralateral ICA is occluded possible. Protective devices were associated with a $38 \%$ decrease in relative periprocedural stroke risk in a systematic review of 134 studies covering more than 23,000 patients $(39,40)$. In all cases in our trial, we believe that endovascular treatment with the use of embolism-blocking filters prevents the risk of embolus during the procedure. Likewise, in our study, during the 30-day follow-ups of all patients, no complication or death due to the procedure occurred. During the one-year follow-up, there was no recurrent stroke or TIA.

Stent complications are related to procedures (intimal dissection, etc.), hemodynamic incidents (hemorrhage etc.) and restenosis. In our study, we determined that there was no periprocedural operation complication. One of the obstacles encountered in stenting is in-stent restenosis. In the most involved case where stenting was performed, the rate for restenosis was reported as 6\% (41). In our study, within the first month of the radiological follow-up of one patient $(n: 1,1.4 \%)$, asymptomatic restenosis was detected. In-stent restenosis was not detected in serial Doppler ultra-sonographies performed in the first, third, sixth, and twelfth months following the procedure, and the flow types and velocities were in normal ranges. For prevention of long-term permanent neurological disorders following endovascular treatment, application of advanced procedural techniques, tight stent control and alleviation of risk factors via medical treatment play a role (42). Antiaggregant and anticoagulant treatments following endovascular treatment play a vital role in keeping the stent open. Although there are various ideas regarding medical treatment, the protocol we applied (acetylsalicylic acid and clopidogrel treatment) is among the protocols reported in the literature (43). Close monitoring of the stent openings of our patients after the procedure and arrangement and regular follow up of their pharmacological and nonpharmacological treatments regarding risk factors affected our long-term results. Furthermore, death or major stroke (ischemic or hemorrhagic) occurred in none of our cases, and in the long-term follow-ups of our patients, permanent neurological disorder was not reported. In our study, the success rate of the outcomes of the endovascular treatment procedures was high; however, it should be noted that precautions were taken against all risk factors mentioned above. Appropriate selection of patients also played an important role.

There were some limitations in our research. It was a retrospective study, the patients were from only one center, and the sample size was small.

\section{CONCLUSION}

We are of the opinion that the factors that increased our operational success and reduced complication rates included careful patient selection for endovascular procedures by complying with strict rules reported in the literature, maximum care in the preprocedural operations of the patients, close monitoring and regulation of situations increasing comorbidity, in addition to close monitoring of vital signs, using an experienced and careful neurovascular team during the periprocedural operation, periprocedural precautions taken by this team, and that the patients were followed-up by a clinician at the neurovascular unit in the postprocedural period for 48 hours including visits with 12-hour intervals and monitoring of vital signs. Along with new pharmacological and technological developments, the field of carotid artery stenting has been growing. Development of better and more easily used equipment and improvement of embolism-blocking drugs and adjuvant pharmacological treatments make carotid artery stenting more attractive. Randomized 
and prospective studies regarding CAS application results, comorbidities and internal, neurological and medical treatments before, during and after the procedure will reveal the role of CAS in improved treatment of occlusive carotid artery disease.

Conflict of interest: Authors declare that there is no conflict of interest between the authors of the article.

Financial conflict of interest: Authors declare that they did not receive any financial support in this study.

Address correspondence to: Hasan Hüseyin Kozak, Necmettin Erbakan University, Meram Faculty of Medicine, Department of Neurology, Meram, 42080, Konya, Turkey E-mail: hhkozak@gmail.com

Phone number: +90 3322237344

\section{REFERENCES}

1. Phatouros CC, Higashida RT, Malek AM, et al. Carotid artery stent placement for atherosclerotic disease: Rationale, technique, and current status. Radiology 2000;217:26-41.

2. Kirsch EC, Khangure MS, van Schie GP, et al. Carotid arterial stent placement: Results and follow-up in 53 patients. Radiology 2001;220:737-44.

3. Longstreth WT Jr, Shemanski L, Lefkowitz D, et al. Asymptomatic internal carotid artery stenosis defined by ultrasound and the risk of subsequent stroke in the elderly. The cardiovascular health study. Stroke 1998;29:2371-6.

4. Halliday A, Harrison M, Hayter E, et al. 10-year stroke prevention after successful carotid endarterectomy for asymptomatic stenosis (ACST-1): A multicentre randomised trial. The Lancet 2010;376(9746):1074-84.

5. Brott TG, Halperin JL, Abbara S, et al. Guideline on the management of patients with extracranial carotid and vertebral artery disease. J Am Coll Cardiol 2011;57(8):51694.

6. Tendera M, Aboyans V, Bartelink ML, et al. ESC Guidelines on the diagnosis and treatment of peripheral artery diseases: Document covering atherosclerotic disease of extracranial carotid and vertebral, mesenteric, renal, upper and lower extremity arteries: The task force on the diagnosis and treatment of peripheral artery diseases of the European Society of Cardiology (ESC). Eur Heart J 2011;32(22):2851906.

7. Wilson PW, Hoeg JM, D'Agostino RB, et al. Cumulative effects of high cholesterol levels, high blood pressure, and cigarette smoking on carotid stenosis. N Engl J Med 1997;337(8):51622.

8. Torvik A. The pathogenesis of watershed infarcts in the brain. Stroke 1984;15(2):221-3.

9. Moriwaki H, Matsumoto M, Hashikawa K, et al. Hemodynamic aspect of cerebral watershed infarction: Assessment of perfusion reserve using iodine-123-lodoamphetamine SPECT. Journal of Nuclear Medicine 1997;38(10):1556-62.

10. Momjian-Mayor I, Baron JC. The pathophysiology of watershed infarction in internal carotid artery disease: Review of cerebral perfusion studies. Stroke 2005;36(3):567-77.

11. O'Brien M, Chandra A. Carotid revascularization: Risks and benefits. Vasc Health Risk Manag 2014;10:403-16.
12. Liu H, Chu J, Zhang L, et al. Clinical comparison of outcomes of early versus delayed carotid artery stenting for symptomatic cerebral watershed infarction due to stenosis of the proximal internal carotid artery. Biomed Res Int 2016;2016:6241546.

13. Zhang $C$, Wang $Y$, Zhao $X$, et al. Clinical, imaging features and outcome in internal carotid artery versus middle cerebral artery disease. PLoS One 2019;14(12):e0225906.

14. Weill C, Suissa L, Darcourt J, et al. The pathophysiology of watershed infarction: A three-dimensional time-offlight magnetic resonance angiography study. J Stroke Cerebrovasc Dis 2017;26(9):1966-73.

15. Ferguson GG, Eliasziw M, Barr HW, et al. The North American symptomatic carotid endarterectomy trial: Surgical results in 1415 patients. Stroke 1999;30(09):1751-8.

16. Randomised trial of endarterectomy for recently symptomatic carotid stenosis: Final results of the MRC European Carotid Surgery Trial (ECST). Lancet 1998;351(9113):1379-87.

17. Villwock MR, Padalino DJ, Deshaies EM. Carotid artery stenosis with acute ischemic stroke: Stenting versus angioplasty. Journal of Vascular and Interventional Neurology 2015;8(4):11.

18. Jones DW, Brott TG, Schermerhorn ML. Trials and frontiers in carotid endarterectomy and stenting. Stroke 2018;49(7):1776-83.

19. Chandler JV, George BP, Kelly AG, et al. For-profit hospital status and carotid artery stent utilization in US hospitals performing carotid revascularization. Stroke 2017;48(11):3161-4.

20. Dumont TM, Rughani Al. National trends in carotid artery revascularization surgery. J Neurosurg 2012;116(06):1251-7.

21. Batchelder AJ, Saratzis A, Ross Naylor A. Editor's choice - overview of primary and secondary analyses from 20 randomised controlled trials comparing carotid artery stenting with carotid endarterectomy. Eur J Vasc Endovasc Surg 2019;58(04):479-93.

22. Bonati LH, Lyrer P, Ederle J, et al. Percutaneous transluminal balloon angioplasty and stenting for carotid artery stenosis. Cochrane Database Syst Rev 2012;(09):CD000515

23. Brott TG, Calvet D, Howard G, et al; Carotid stenosis trialists' collaboration. Long-term outcomes of stenting and endarterectomy for symptomatic carotid stenosis: A preplanned pooled analysis of individual patient data. Lancet Neurol 2019;18(04):348-56.

24. Müller MD, Lyrer P, Brown MM, et al. Carotid artery stenting versus endarterectomy for treatment of carotid artery stenosis. Cochrane Database Syst Rev 2020;2(2):CD000515.

25. Bagley JH, Priest R. Carotid revascularization: Current practice and future directions. Semin Intervent Radiol 2020;37(2):132-9.

26. North American Symptomatic Carotid Endarterectomy Trial Collaborators. Beneficial effect of carotid endarterectomy in symptomatic patients with high-grade carotid stenosis. N Engl J Med 1991;325:445-53.

27. Brott TG, Hobson RW, Howard G, et al. Stenting vs endarterectomy for treatment of carotid-artery stenosis. N Engl J Med 2010;363:11-23.

28. Barnett HJ, Taylor DW, Eliasziw M, et al. Benefit of carotid endarterectomy in patients with symptomatic moderate or severe stenosis. North American Symptomatic Carotid Endarterectomy Trial Collaborators. N Engl J Med 1998;339:1415-25.

29. Fine-Edelstein JS, Wolf PA, O'Leary DH, et al. Precursors of 
extracranial carotid atherosclerosis in the framingham study. Neurology 1994;44:1046-50.

30. Mannami T, Baba S, Ogata J. Strong and significant relationships between aggregation of major coronary risk factors and the acceleration of carotid atherosclerosis in the general population of a Japanese city: The suita study. Arch Intern Med 2000;160:2297-303.

31. Ederle J, Brown MM. The evidence for medicine versus surgery for carotid stenosis. Eur J Radiol 2006;60:3-7.

32. Randomised trial of endarterectomy for recently symptomatic carotid stenosis: Final results of the MRC European Carotid Surgery Trial (ECST). Lancet 1998;351:1379-87.

33. Endovascular versus surgical treatment in patients with carotid stenosis in the carotid and vertebral artery transluminal angioplasty study (CAVATAS): A randomised trial. Lancet 2001;357:1729-37.

34. Sheffet AJ, Roubin G, Howard G, et al. Design of the carotid revascularization endarterectomy vs. stenting trial (CREST). Int J Stroke 2010;5:40-6.

35. Rothwell PM. Symptomatic and asymptomatic carotid stenosis: How, when, and who to treat? Curr Atheroscler Rep 2006;8:290-7.

36. Endarterectomy for asymptomatic carotid artery stenosis. Executive committee for the asymptomatic carotid atherosclerosis study. JAMA 1995;273:1421-8.

37. Kappelle LJ. Symptomatic carotid artery stenosis. J Neurol 2002;249:254-9.

38. Brott TG, Halperin JL, Abbara S, et al. 2011 ASA/ACCF/ AHA/AANN/AANS /ACR/ASNR/CNS/SAIP/SCAI/SIR/SNIS/ SVM/SVS guideline on the management of patients with extracranial carotid and vertebral artery disease. A report of the American College of Cardiology Foundation/American Heart Association Task Force on Practice Guidelines, and the American Stroke Association, American Association of Neuroscience Nurses, American Association of Neurological Surgeons, American College of Radiology, American Society of Neuroradiology, Congress of Neurological Surgeons, Society of Atherosclerosis Imaging and Prevention, Society for Cardiovascular Angiography and Interventions, Society of Interventional Radiology, Society of Neurolnterventional Surgery, Society for Vascular Medicine, and Society for Vascular Surgery. Circulation 2011;124: e54-130.
39. Kastrup A, Gröschel K, Krapf H, et al. Early outcome of carotid angioplasty and stenting with and without cerebral protection devices: A systematic review of the literature. Stroke 2003;34(03):813-9.

40. Garg N, Karagiorgos N, Pisimisis GT, et al. Cerebral protectiondevices reduce periprocedural strokes during carotid angioplasty and stenting: A systematic review of the current literature. J Endovasc Ther 2009;16(04):412-27.

41. Theron JG, Payelle GG, Coskun O, et al. Carotid artery stenosis: Treatment with protected balloon angioplasty and stent placement. Radiology 1996;201:627-36.

42. Biller J, Feinberg WM, Castaldo JE, et al. Guidelines for carotid endarterectomy: A statement for healthcare professionals from a specific writing group of the Stroke Council, American Heart Association. Stroke 1998;29:554-62.

43. Barr JD, Connors JJ, Sacks D, et al. Quality improvement guidelines for the performance of cervical carotid angioplasty and stent placement. Am J Neuroradiol 2003;24:2020-34. 